\title{
STUDI KOMPARASI PENGGUNAAN KONTRASEPSI DENGAN PERUBAHAN BERAT BADAN PADA AKSEPTOR KB SUNTIK 1 BULAN DAN 3 BULAN DI PUSKESMAS RAWAT INAP SIDOMULYO PEKANBARU
}

\author{
Susani Hayati \\ Program Studi DIII Kebidanan STIKes Payung Negeri \\ Korespondensi penulis: hayatisusani@gmail.com
}

\begin{abstract}
Abstrak
Latar belakang dan tujuan: Penggunaan kontrasepsi merupakan salah satu upaya untuk pengendalian pertumbuhan penduduk yang paling efektif. Salah satu metode kontrasepsi yang populer adalah metode suntik. Kontrasepsi KB suntik terdiri dari KB suntik 1 bulan dan 3 bulan. Efek samping yang sering terjadi dan dikeluhkan oleh akseptor KB suntik adalah perubahan berat badan. Tujuan dari penelitian ini adalah untuk mengetahui perbedaan perubahan berat badan Kontrasepsi Suntik 1 bulan dan 3 bulan.

Metode: Penelitian ini bersifat kuantitatif dengan desain penelitian comparatif study, menggunakan pendekatan cross sectional. Penelitian dilakukan di wilayah kerja Puskesmas Rawat Inap Sidomulyo pada bulan Desember 2018. Jumlah sampel 21 akseptor KB suntik 1 bulan dan 20 akseptor KB suntik 3 bulan yang didapat secara purposive sampling. Instrumen penelitian menggunakan kuesioner analisa data menggunakan uji Mann-Whitney Test.

Hasil: Hasil penelitian menunjukkan rerata peringkat perubahan berat badan kelompok suntik 1 bulan 17,21 lebih rendah dari kelompok suntik 3 bulan 24,98.

Simpulan: Terdapat perbedaan bermakna $p$ value $0,036<0,05$ perubahan berat badan penggunaan kontrasespsi suntik 1 bulan dan 3 bulan. Diharapkan pihak Puskesmas Sidomulyo agar dapat meningkatkan konseling kepada ibu yang menggunakan kontrasepsi KB suntik tentang masalah perubahan berat badan.
\end{abstract}

Kata Kunci : Kontrasepsi, Perubahan berat badan, Suntik 1 bulan, Suntik 3 bulan

\section{Pendahuluan}

Peraturan Pemerintah Republik Indonesia Nomor 87 Tahun 2014 tentang Perkembangan Kependudukan dan Pembangunan Keluarga, Keluarga Berencana, dan Sistem Informasi Keluarga menyebutkan bahwa program keluarga berencana (KB) adalah upaya mengatur kelahiran anak, jarak dan usia ideal melahirkan, mengatur kehamilan, melalui promosi, perlindungan, dan bantuan sesuai dengan hak reproduksi untuk mewujudkan keluarga yang berkualitas. Menurut UU No. 52 tahun 2009 keluarga berkualitas adalah keluarga yang dibentuk berdasarkan perkawinan yang sah dan bercirikan sejahtera, sehat, maju, mandiri, memiliki jumlah anak yang ideal, berwawasan kedepan, bertanggung jawab, harmonis, dan bertaqwa kepada Tuhan Yang Maha Esa.

Menurut WHO (World Health Organitation) keluarga berencana adalah tindakan yang membantu individu atau pasangan suami-istri untuk mengatur interval diantara kelahiran, menentukan jumlah anak dalam keluarga, serta mendapatkan kelahiran yang memang diinginkan. Hal ini dilakukan untuk mendapatkan keluarga yang sejahtera. Menurut UU No. 52 tahun 2009, Keluarga Berencana adalah upaya mengatur kelahiran 
anak, jarak dan usia ideal melahirkan, mengatur kehamilan, melalui promosi, perlindungan, dan bantuan sesuai dengan hak reproduksi untuk mewujudkan keluarga yang berkualitas.

Hasil Riskesdas 2013, pemakaian cara/alat KB di Indonesia sebesar 59,7 persen dan CPR modern sebesar 59,3 persen. Diantara penggunakan cara KB suntikan (34,3\%), dan merupakan penyumbang terbesar pada kelompok non MKJP dan jenis hormonal (Riskesdas, 2013). Berdasarkan data dari Kementrian Kesehatan Republik Indonesia Tahun 2017, jumlah penduduk di Riau sebanyak 6.657.911 jiwa yang terdiri dari 3.416.307 jiwa laki-laki dan 3.241.604 jiwa perempuan. Untuk jumlah pasangan usia subur sekitar 742.522 pasangan, yang terdaftar KB aktif sebesar 387.206 jiwa $(52,15 \%)$. Dari 387.206 jiwa yang terdaftar sebagai KB aktif, KB suntik menjadi pilihan yang paling banyak dipilih oleh pasangan usia subur sejumlah 243.101 jiwa $(62,78 \%)$.

Kontrasepsi suntik dibagi menjadi dua, yaitu suntikan kombinasi dan suntikan progestin. Kontrasepsi suntik kombinasi sering juga disebut sebagai suntikan KB 1 bulan dikarenakan metode ini menggunakan hormon estrogen dan progestin yang diberikan kepada pasangan usia subur 4 minggu sekali. Sedangkan kontrasepsi progestin hanya mengandung hormon progesterone saja. Suntikan jenis ini sering dikenal sebagai kontrasepsi suntik 3 bulan karena pasangan usia subur yang menggunakan metode ini mendapatkan suntikan 12 minggu sekali. Semua alat kontrasepsi pasti ada keuntungan dan kerugian, begitu juga memiliki dampak baik dan dampak buruk bagi pengguna. Sedangkan dampak buruk dari KB suntik diantaranya adalah gangguan pola menstruasi, keterlambatan kembali subur sampai satu tahun, peningkatan berat badan, emosi sering tidak stabil, sakit kepala, depresi, tidak menjamin perlindungan terhadap infeksi menular seksual (Sumayan, 2017)

Efek samping yang sering terjadi dan dikeluhkan oleh akseptor KB suntik adalah penambahan berat badan. Pertambahan berat badan menjadi masalah bagi sebagian kecil pemakai estriol dan turunan progesteron. Sedangkan untuk pemakai KB suntik yang hanya berisi progesteron saja, bisa terjadi peningkatan 1-2 kg pada tahun pertama serta 4-10 kg setelah 3-5 tahun penggunaan. Waktu lamanya pemakaian KB suntik dapat mempengaruhi peningkatan berat badan yang disebabkan oleh hormon progesteron yang menjadikan nafsu makan meningkat dipusat pengendalian hyipotalamus (Nault, A. et al, 2013)

Data Dinas Kesehatan Kota Pekanbaru, jumlah peserta KB aktif yang paling tinggi berada di Kota Pekanbaru dengan penggunaan sebanyak 130.338 jiwa. Sebanyak 57.140 jiwa $(43,8 \%)$ masyarakat Pekanbaru memilih alat kontrasepsi jenis KB suntik. Menurut data Dinas Kesehatan Kota Pekanbaru, Kecamatan Tampan memiliki data tertinggi KB aktif sebanyak 17.699 orang. Dari data tersebut, Puskesmas Sidomulyo menjadi tempat pelayanan kesehatan yang memiliki data penggunaan kontrasepsi jenis KB Suntik tertinggi sebanyak 6.354 jiwa.

Berdasarkan uraian latar belakang di atas peneliti tertarik untuk mengetahui lebih jauh tentang salah satu efek samping kontrasepsi suntik ini, dengan rumusan masalah "Bagaimana Perbedaan Perubahan Berat Badan Ibu Pengguna Kontrasepsi Suntik Satu Bulan dan Tiga Bulan”.

\section{Metode Penelitian}

Penelitian ini bersifat kuantitatif dengan desain penelitian comparatif study, menggunakan pendekatan cross sectional. Penelitian ini bermaksud untuk membandingkan perubahan berat badan akseptor suntik 1 bulan dengan suntik 3 bulan. Penelitian dilakukan di wilayah kerja Puskesmas Rawat Inap Sidomulyo pada bulan Desember 2018. Jumlah sampel 21 akseptor KB suntik 1 bulan dan 20 akseptor KB suntik 3 bulan dengan jumlah total 41 orang yang didapat secara purposive sampling dengan kriteria inklusi adalah akseptor KB yang telah memakai suntikan 
selama 2-3 tahun. Instrumen penelitian menggunakan kuesioner, wawancara dan observasi penimbangan berat badan. Analisa data menggunakan uji Mann-Whitney Test (Hidayat, 2017).

\section{Hasil dan Pembahasan}

Hasil penelitian studi perbandingan perubahan berat badan pada akseptor KB suntik 1 bulan dengan akseptor KB suntik 3 bulan terhadap 21 orang responden, yang dilakukan pada bulan Desember 2018 adalah sebagai berikut:

\section{Karakteristik Responden}

Tabel 1. Distribusi Frekuensi Karakteristik Responden KB Suntik

\begin{tabular}{clcccc}
\hline No & \multicolumn{1}{c}{ Karakteristik } & & Suntik 1 bulan & & Suntik 3 bulan \\
\hline $\mathbf{1}$ & Umur & $\mathbf{n}$ & $\mathbf{\%}$ & $\mathbf{n}$ & $\mathbf{\%}$ \\
& $<20$ tahun & 0 & 0 & 0 & 0 \\
& $20-35$ tahun & 17 & 80,9 & 20 & 100 \\
& $>30$ tahun & 4 & 19,1 & 0 & 0 \\
& Total & 21 & 100 & 20 & 100 \\
\hline $\mathbf{2}$ & Pendidikan & & & & \\
& Dasar & 7 & 33,3 & 4 & 20,0 \\
& Menengah & 6 & 28,6 & 13 & 65,0 \\
& Tinggi & 8 & 38,1 & 3 & 15,0 \\
& Total & 21 & 100 & 20 & 100 \\
\hline $\mathbf{3}$ & Pekerjaan & & & & \\
& Bekerja & 8 & 38,1 & 5 & 25,0 \\
& Tidak bekerja & 13 & 61,9 & 15 & 75,0 \\
& Total & 21 & 100 & 20 & 100 \\
\hline $\mathbf{4}$ & Jumlah anak & & & & \\
& 1 & 10 & 47,6 & 12 & 60,0 \\
& $>1$ & 11 & 52,4 & 8 & 40,0 \\
& Total & 21 & 100 & 20 & 100 \\
\hline $\mathbf{5}$ & Lama penggunaan KB & & & & \\
& 2 tahun & 12 & 57,1 & 7 & 35,0 \\
3 tahun & 9 & 42,9 & 13 & 65,0 \\
& Total & 21 & 100 & 20 & 100 \\
\hline
\end{tabular}

Berdasarkan Tabel 1 dapat diketahui bahwa, mayoritas umur akseptor KB suntik 1 bulan adalah 20-35 tahun yaitu 17 responden $(80,9)$, begitu juga dengan semua akseptor KB suntik 3 bulan yaitu 20 responden $(100 \%)$. Mayoritas tingkat pendidikan akseptor KB suntik 1 bulan adalah pendidikan tinggi yaitu 8 responden $(38,1 \%)$, sedangkan akseptor KB suntik 3 bulan adalah pendidikan menengah yaitu 13 responden $(65,0 \%)$. Mayoritas pekerjaan akseptor KB suntik 1 bulan adalah tidak bekerja yaitu 13 responden $(61,9 \%)$, begitu juga dengan akseptor KB suntik 3 bulan yaitu 15 responden (75\%). Mayoritas jumlah anak akseptor KB suntik 1 bulan adalah 1 anak yaitu 12 responden $(60,0 \%)$, sedangkan akseptor KB suntik 3 bulan adalah $>1$ yaitu
11 responden (52,4\%). Mayoritas lama pemakaian kontrasepsi suntik 1 bulan adalah 2 tahun yaitu 12 responden $(57,1 \%)$, sedangkan akseptor KB suntik 3 bulan adalah 3 tahun yaitu 13 responden yaitu (65\%). 
Analisis Univariat

Tabel 2 Distribusi Frekuensi Perubahan Berat Badan Akseptor KB Berdasarkan Jenis Kontrasepsi

\begin{tabular}{llccc}
\hline \multirow{2}{*}{ No } & \multirow{2}{*}{ Jenis Kontrasepsi } & \multicolumn{3}{c}{ Perubahan Berat badan } \\
\cline { 3 - 5 } & & & n & $\%$ \\
\hline \multirow{2}{*}{ Suntik 1 bulan } & $\leq 5 \mathrm{~kg}$ & 7 & 33,3 \\
& & $>5 \mathrm{~kg}$ & 14 & 66,7 \\
& & 21 & 100 \\
\hline \multirow{2}{*}{2} & \multirow{2}{*}{ Suntik 3 bulan } & $\leq 5 \mathrm{~kg}$ & 4 & 20 \\
& & $>5 \mathrm{~kg}$ & 16 & 80 \\
& & & 20 & 100 \\
\hline
\end{tabular}

Berdasarkan tabel 2 di atas dapat terlihat bahwa mayoritas perubahan berat badan pada akseptor $\mathrm{KB}$ suntik 1 bulan adalah $>5 \mathrm{~kg}$ yaitu 14 responden $(66,7 \%)$. Sedikit lebih tinggi perubahan berat badan pada akseptor $\mathrm{KB}$ suntik 3 bulan $>5 \mathrm{~kg}$ yaitu 16 reponden $(80 \%)$.

Analisis Bivariat

Tabel 3. Hasil Uji Mann-Whitney Perbedaan Perubahan Berat Badan Akseptor KB Suntik 1 bulan dengan Akseptor KB Suntik 3 bulan

\begin{tabular}{cclcc}
\hline & Variabel & Mean Rank & z hitung & Signifikansi \\
\cline { 1 - 2 } Berat badan & Suntik 1 bulan & 17,21 & $-2,094$ & \multirow{2}{*}{0,036} \\
\hline
\end{tabular}

Pada tabel 3 di atas menunjukkan mean rank atau rata-rata peringkat perubahan berat badan pada kelompok akseptor KB suntik 1 bulan yaitu 17,21 lebih rendah dari pada ratarata peringkat kelompok KB suntik 3 bulan yaitu 24,98. Secara statistik uji Mann whitney nilai $\mathrm{z}$ hitung $-2,094$ dan nilai $\mathrm{p}$ value $0,036<$ 0,05 , maka hasil tersebut membuktikan hipotesis $\mathrm{Ha}$ diterima terdapat perbedaan yang bermakna antara kelompok akseptor $\mathrm{KB}$ suntik 1 bulan dengan akseptor KB suntik 3 bulan. Nilai $\mathrm{z}$ hitung negatif menunjukkan bahwa perubahan berat badan lebih besar pada kelompok kedua, yaitu kelompok akseptor KB suntik 3 bulan

Hal ini sesuai dengan teori yang menyatakan hormon progesteron mempermudah terjadinya perubahan gula dan karbohidrat menjadi lemak, sehingga lemak banyak yang bertumpuk di bawah kulit, selain itu suntik 3 bulan dapat merangsang pusat pengendali nafsu makan di hipotalamus yang dapat menyebabkan akseptor makan lebih banyak dari biasanya akibatnya pemakaian suntikan dapat menyebabkan berat badan bertambah (Hartanto, 2009).

Sesuai dengan hasil penelitian Santoso, 2018 menunjukkan perbandingan perubahan berat badan sesudah pada akseptor KB suntik 1 bulan dan 3 bulan terdapat perbedaan yang signifikan nilai $p$ value $0,003<0,05$. Pendapat lainnya menyatakan penggunaan jangka panjang kontrasepsi suntik dapat memicu terjadinya peningkatan berat badan, kanker, gangguan emosi, dan jerawat karena penggunaan suntikan hormonal yang lama dapat mengganggu keseimbangan hormon estrogen dan progesteron dalam tubuh sehingga mengakibatkan terjadi perubahan sel yang normal menjadi tidak normal. Risiko kenaikan berat badan kemungkinan disebabkan karena hormon progesteron yang mempermudah perubahan karbohidrat dan gula menjadi lemak, sehingga lemak di bawah kulit bertambah, selain itu hormon progesteron juga menyebabkan nafsu makan bertambah dan menurunkan aktivitas fisik, akibatnya pemakaian kontrasepsi suntik dapat menyebabkan berat badan bertambah (Saifuddin, 2006).

\section{Simpulan}

Mayoritas perubahan berat badan pada akseptor KB suntik 3 bulan adalah $>5 \mathrm{~kg}$ yaitu 16 responden $(80 \%)$, sedikit lebih tinggi perubahan berat badan pada akseptor KB 
suntik 1 bulan $>5 \mathrm{~kg}$ yaitu 14 reponden $(66,7 \%)$.Terdapat perbedaan yang bermakna antara kelompok akseptor KB suntik 1 bulan dengan akseptor KB suntik 3 bulan. Perubahan berat badan cenderung lebih besar pada akseptor KB suntik 3 bulan.

\section{Referensi}

Arum, S, 2011. Panduan Lengkap Pelayanan KB Terkini. Jogjakarta; Nuha Offset

Azwar \& Hayati. 2013, Keluarga Berencana. Pekanbaru; STIKes Payung Negeri.

Budi, N. 2017. Efek Samping Akseptor Kb Suntik Depo Medroksi Progesterone Acetat (Dmpa) Setelah 2 Tahun Pemakaian. Yogyakarta. Samodra Ilmu

Dinas Kesehatan. 2018. Profil Kesehatan Provinsi Riau Tahun 2018. Pekanbaru; Dinas Kesehatan Provinsi Riau

Dinas Kesehatan. 2018. Profil Kesehatan Kota Pekanbaru Tahun 2018. Pekanbaru; Dinas Kesehatan Kota Pekanbaru

Everett, S. 2012. Kontrasepsi dan Kesehatan Seksual Reproduktif. Jakarta; EGC

Hartanto, H., 2009, Keluarga Berencana dan Kontrasepsi, Jakarta: Pustaka Sinar Harapan

Hidayat, A, 2017. Tutorial Uji Mann Whitney $U$ Test dengan SPSS. Diperoleh dari www.statistikian.com

Irianto, K. 2014. Pelayanan Keluarga Berencana Dua Anak Cukup. Bandung; Alfabeta

Kementerian Kesehatan Republik Indonesia. 2017. Data dan Informasi Profil Kesehatan Indonesia Tahun 2017. Jakarta; Kementerian Kesehatan Republik Indonesia

Nault, A, Peipert J., Zhao, Q., Madden, T., Secure, G. (2013). Validity of Perceived Weight Gain In Women Using Long-Acting Reversible Contraception and Depot Medroxyprogesterone Acetat, January 208 (4) pp. 48.el-48.e.8.
Available from: http//american journal of obsetetrics \& gynecology.

Notoatmodjo S. 2010. 2012. Metodologi Penelitian Kesehatan Revisi Kedua. Jakarta; PT Rineka Cipta

Permen RI. 2014. Peraturan Pemerintah Republik Indonesia Nomor 87 Tahun 2014 Tentang Perkembangan Kependudukandan Pembangunan Keluarga Keluarga Berencana, Dan Sistem Informasi Keluarga. Jakarta; Permen RI.

Pinem, S. 2009. Kesehatan Reproduksi dan Kontrasepsi. Jakarta; Trans Info Media

Pratiwi, Syahredi, Erkadius. 2014. Hubungan Antara PenggunaanKontrasepsi Hormonal Suntik Dengan Peningkatan Berat Badan Di Puskesmas Lapai Kota Padang. Padang; Jurnal FK UNAND

Profil Kesehatan Indonesia. 2016. Profil Kesehatan Indonesia Tahun 2017. Jakarta; Kementerian Kesehatan Republik Indonesia

Riskesdas. 2013. Riset Kesehatan Dasar 2013. Jakarta; Bapelbangkes Kemenkes RI

Saifuddin, A.B., B. Affandy, \& Enriquito, R. LU., 2006, Panduan Praktis Pelayanan Kontrasepsi, Jakarta: Yayasan Bina Pustaka Prawirohardjo.

Santoso, RYP. 2019. Analisis Perbedaan Perubahan Berat Badan Ibu Pengguna Kontrasepsi Suntik Satu Bulan dan Tiga Bulan. Surakarta, Universitas Muhammadiyah Surakarta

Sumayan, R, R. 2017. Studi Pengalaman Akseptor Kb Tentang Pemakaian KB Suntik 3 Bulan Di Puskesmas Pallangga Kabupaten Gowa Tahun 2017. Makasar; UIN Alaudin

Undang-Undang Republik Indonesia. 2009. UU No. 52 Tentang Perkembangan Kependudukan Dan Pembangunan Keluarga. Jakarta; UU 